\title{
Solid-state Syntheses and Single-crystal Characterizations of Three Tetravalent Thorium and Uranium Silicates
}

\author{
Geng Bang Jin, ${ }^{*}$ L. Soderholm
}

Chemical Sciences and Engineering Division, Argonne National Laboratory, Argonne, IL 60439

\begin{abstract}
Colorless crystals of $\mathrm{ThSiO}_{4}$ (huttonite) (1) and $\left(\mathrm{Ca}_{0.5} \mathrm{Na}_{0.5}\right)_{2} \mathrm{NaThSi}_{8} \mathrm{O}_{20}(2)$ have been synthesized by the solid-state reactions of $\mathrm{ThO}_{2}, \mathrm{CaSiO}_{3}$, and $\mathrm{Na}_{2} \mathrm{WO}_{4}$ at $1073 \mathrm{~K}$. Green crystals of $\left(\mathrm{Ca}_{0.5} \mathrm{Na}_{0.5}\right)_{2} \mathrm{NaUSi}_{8} \mathrm{O}_{20}$ (3) have been synthesized by the solid-state reactions of $\mathrm{UO}_{2}, \mathrm{CaSiO}_{3}$, and $\mathrm{Na}_{2} \mathrm{WO}_{4}$ at $1003 \mathrm{~K}$. All three compounds have been characterized by single-crystal X-ray diffraction. Compound $\mathbf{1}$ adopts a monazite-type three-dimensional condensed structure, which is built from edge- and corner-shared $\mathrm{ThO}_{9}$ polyhedra and $\mathrm{SiO}_{4}$ tetrahedra. Compound $\mathbf{2}$ and $\mathbf{3}$ are isostructural and they crystallize in a steacyite-type structure. The structure consists of discrete pseudocubic $\left[\mathrm{Si}_{8} \mathrm{O}_{20}\right]^{8-}$ polyanions, which are connected by $\mathrm{An}^{4+}$ cations into a three-dimensional framework. Each An atom coordinates to eight monodentate $\left[\mathrm{Si}_{8} \mathrm{O}_{20}\right]^{8-}$ moieties in a square antiprismatic geometry. $\mathrm{Na}^{+}$and $\mathrm{Ca}^{2+}$ ions reside in the void within the framework. Raman spectra of $\mathbf{1}, \mathbf{2}$, and $\mathbf{3}$ were collected on single crystal samples. $\mathbf{1}$ displays more complex vibrational bands than thorite. Raman spectra of $\mathbf{2}$ and $\mathbf{3}$ are analogous with most of vibrational bands located at almost the same regions.
\end{abstract}

Keywords: Thorium; Uranium; Silicate; Solid-state syntheses; Single-crystal structure; Raman Spectroscopy

* Corresponding author:

Geng Bang Jin

CHM/200

Argonne National Laboratory

9700 S. Cass Ave., Argonne, IL

Email: gjin@anl.gov

Phone : 6302523658

\section{Introduction}


The natural formation of silicate minerals has involved a range of processes that include partial melting and crystallization. Because silicate phases are a significant class of minerals observed for natural actinides [1-8], as exemplified by thorite $\left(\mathrm{ThSiO}_{4}\right)$ [1] and coffinite $\left(\mathrm{USiO}_{4}\right)$ [3], we are interested in developing synthetic routes from melts that can be used to extend this chemistry to the man-made heavier actinides, $\mathrm{Np}$ and $\mathrm{Pu}$. Knowledge in this area is critical to furthering our predictive capabilities regarding the fate and transport of transuranic contaminants in the geosphere $[9,10]$.

The current research of actinide silicates, particularly those containing lower-valent actinides (III/IV) has been largely hindered by the difficulty in the material syntheses [11-15]. For example, synthesis of pure $\mathrm{USiO}_{4}$ proves to remain challenging to date, which has prevented the determination of accurate thermodynamic values until recently $[12,14,15]$. Binary actinide and silicon oxides and most of metal silicates have low solubility in common solvents and high melting points (eg. $\mathrm{ThO}_{2}$ : insoluble in water with a melting point of $3660 \mathrm{~K}$ ). Harsh synthetic conditions such as high pressure and high temperature $(>1273 \mathrm{~K})$ are typically required to allow the reactants to reach reasonable diffusion rates $[11,13,16,17]$. Most actinides except Th are redox active, which poses additional challenges over the syntheses [18]. Hydrothermal methods have been widely used to prepare silicate materials including uranyl silicates [19, 20], however there is limited success in stabilizing lower-valent actinides under these conditions [12, 13]. As a result, the number of actinide (III/IV) silicates reported in the literature is rather small even for Th or U phases [5-8, 13, 21-24]. Most of studies have focused on actinide orthosilicates and a few of other actinide-contained silicate minerals such as arapovite $\left((\mathrm{CaNa})_{2}\left(\mathrm{~K}_{1-\mathrm{x}} \square_{\mathrm{x}}\right) \mathrm{USi}_{8} \mathrm{O}_{20}\right)[8]$ and ekanite $\left(\mathrm{Ca}_{2} \mathrm{ThSi}_{8} \mathrm{O}_{20}\right)$ [25]. The only additions to the minerals and their related phases are recently discovered $\mathrm{Cs}_{2} \mathrm{ThSi}_{6} \mathrm{O}_{15}$ [22], $\mathrm{Cs}_{2} \mathrm{USi}_{6} \mathrm{O}_{15}$ [13], and several U(IV)-contained mixedvalent uranium silicates [26-28] in laboratories.

Herein, we report the single-crystal growth of $\mathrm{ThSiO}_{4}$ (huttonite) (1) and two new compounds, $\left(\mathrm{Ca}_{0.5} \mathrm{Na}_{0.5}\right)_{2} \mathrm{NaThSi}_{8} \mathrm{O}_{20}$ (2), and $\left(\mathrm{Ca}_{0.5} \mathrm{Na}_{0.5}\right)_{2} \mathrm{NaUSi}_{8} \mathrm{O}_{20}$ (3) using a ternary precursor and a $\mathrm{Na}_{2} \mathrm{WO}_{4}$ flux in silica ampoules at much lower temperatures (several hundreds of degrees) than previous solid-state studies. Naturally occurring huttonite has been synthesized in powder form by a hydrothermal process [11] or from sintering $\mathrm{ThO}_{2}$ and $\mathrm{SiO}_{2}$ at $1773 \mathrm{~K}$ [29]. 
Alternatively, single-crystal samples have been obtained by heating two binary oxides in a $\mathrm{Li}_{2} \mathrm{WO}_{4}$ or a $\mathrm{Na}_{2} \mathrm{WO}_{4}$ melt at $1523 \mathrm{~K}[16,17]$. It is noted that, compounds 2 and $\mathbf{3}$ are closely related to the minerals, steacyite and turkestanite $\left((\mathrm{CaNa})_{2}\left(\mathrm{~K}_{1-\mathrm{x}} \square_{\mathrm{x}}\right) \mathrm{ThSi}_{8} \mathrm{O}_{20}\left(\mathrm{H}_{2} \mathrm{O}\right)_{\mathrm{n}}\right)[5,6]$, and arapovite $\left((\mathrm{CaNa})_{2}\left(\mathrm{~K}_{1-\mathrm{x}} \square_{\mathrm{x}}\right) \mathrm{USi}_{8} \mathrm{O}_{20}\right)$ [8]. Powder samples of synthetic analogous of Th minerals, $\mathrm{KNaCaThSi}_{8} \mathrm{O}_{20}$ [23] and $\mathrm{RbNaCaThSi}_{8} \mathrm{O}_{20}$ [24] have been synthesized very recently from solidstate reactions of metal nitrates and silicon oxides at $1420 \mathrm{~K}$.

We also report structural and Raman spectroscopic studies on single crystal samples of $\mathbf{1}$, 2, and 3. Raman spectroscopy has been widely used to gain structural and compositional information of silicate materials [30]. Extensive Raman studies on zircon-type compounds including $\mathrm{ZrSiO}_{4}, \mathrm{HfSiO}_{4}, \mathrm{ThSiO}_{4}$ (thorite), and $\mathrm{USiO}_{4}$ have been reported in the literature [3133]; However no study has been conducted on huttonite, which is the high-temperature polymorph of thorite. To our knowledge, this is the first reported Raman spectrum for single crystals of huttonite. Recently, Clavier et al. have demonstrated the use of Raman spectroscopy as a promising tool for the semi-quantitative determination of chemical composition of uranothorite samples $\left(\mathrm{Th}_{1-\mathrm{x}} \mathrm{U}_{\mathrm{x}} \mathrm{SiO}_{4}\right)$ [33]. Our results on isostructural compounds $\mathbf{2}$ and $\mathbf{3}$ are used to further assess this potential application of Raman spectroscopy for actinide silicate materials.

\section{Experiments}

Caution! ${ }^{232} \mathrm{Th}$ and ${ }^{238} \mathrm{U}$ are $\alpha$ emitting radioisotopes and as such are considered a health risk. Their use requires appropriate infrastructure and personnel trained in the handling of radioactive materials

\subsection{Syntheses}

$\mathrm{ThO}_{2}$ (International Bio-Analytical Industries, Inc), $\mathrm{UO}_{2}$ (International Bio-Analytical Industries, Inc), $\mathrm{CaSiO}_{3}$ (Cerac, 99.5\%), and $\mathrm{Na}_{2} \mathrm{WO}_{4}$ (MP Biomedicals) were used as received. For both reactions, the reactants were loaded into carbon coated fused-silica ampoules and then 
flame-sealed under vacuum. The reaction mixtures were placed in a computer-controlled furnace and heated to $1073 \mathrm{~K}$ (Th reaction) or $1003 \mathrm{~K}$ (U reaction) in $30 \mathrm{~h}$, held at this temperature for $140 \mathrm{~h}$, slowly cooled to $748 \mathrm{~K}$ (Th reaction) or $703 \mathrm{~K}$ (U reaction) in $150 \mathrm{~h}$, and then cooled to $298 \mathrm{~K}$ in $6 \mathrm{~h}$. The reaction products were washed with water and dried with acetone. Crystals found in these reactions were characterized by single-crystal X-ray diffraction methods.

$\mathbf{T h S i O}_{4}(\mathbf{1})$ and $\left(\mathrm{Ca}_{0.5} \mathbf{N a}_{0.5}\right)_{2} \mathbf{N a T h S i}_{8} \mathbf{O}_{20}$ (2). $0.020 \mathrm{~g}(0.076 \mathrm{mmol})$ of $\mathrm{ThO}_{2}$ and $0.016 \mathrm{~g}$ $(0.138 \mathrm{mmol})$ of $\mathrm{CaSiO}_{3}$ were thoroughly ground together before loading into an ampoule with $0.090 \mathrm{~g}(0.306 \mathrm{mmol})$ of $\mathrm{Na}_{2} \mathrm{WO}_{4}$. A large number of colorless prismatic crystals of $\mathbf{1}$ and colorless cubic crystals of $\mathbf{2}$ co-formed in the same bulk reaction product. Both compounds are stable in air. The yields of $\mathbf{1}$ and $\mathbf{2}$ are difficult to estimate owing to the similar appearance of crystals and broken glass pieces.

$\left(\mathrm{Ca}_{\mathbf{0 . 5}} \mathrm{Na}_{0.5}\right)_{2} \mathrm{NaUSi}_{\mathbf{8}} \mathrm{O}_{20}(3) .0 .010 \mathrm{~g}(0.037 \mathrm{mmol})$ of $\mathrm{UO}_{2}$ and $0.034 \mathrm{~g}(0.293 \mathrm{mmol})$ of $\mathrm{CaSiO}_{3}$ were thoroughly ground together before loading into an ampoule with $0.080 \mathrm{~g}(0.273$ mmol) of $\mathrm{Na}_{2} \mathrm{WO}_{4}$. The reaction products included green cubic crystals of $\mathbf{3}$, which grow among other powder products including unreacted brown $\mathrm{UO}_{2}$, white $\mathrm{CaWO}_{4}$ and some unidentified white phases. A complete separation of green crystals from other products failed. The yield of $\mathbf{3}$ is estimated to around $70 \%$ from a visual inspection. After removing the broken glass, the products were ground into a powder and characterized by powder X-ray diffraction measurements.

\subsection{Structure determination}

Single-crystal X-ray diffraction data for $\mathrm{ThSiO}_{4}$ (1), $\left(\mathrm{Ca}_{0.5} \mathrm{Na}_{0.5}\right)_{2} \mathrm{NaThSi}_{8} \mathrm{O}_{20}$ (2), and $\left(\mathrm{Ca}_{0.5} \mathrm{Na}_{0.5}\right)_{2} \mathrm{NaUSi}_{8} \mathrm{O}_{20}$ (3) were collected with the use of graphite-monochromatized MoK $\alpha$ radiation $(\lambda=0.71073 \AA)$ at $100 \mathrm{~K}$ on a Bruker APEX2 diffractometer [34]. The crystal-todetector distance was $5.106 \mathrm{~cm}$. Data were collected by a scan of $0.3^{\circ}$ in $\omega$ in groups of 600 frames at $\phi$ settings of $0^{\circ}, 90^{\circ}, 180^{\circ}$, and $270^{\circ}$. The exposure time was $20 \mathrm{~s} /$ frame for $\mathbf{1}, 80$ $\mathrm{s} /$ frame for $\mathbf{2}$, and $50 \mathrm{~s} /$ frame for $\mathbf{3}$, respectively. The collection of intensity data as well as cell refinement and data reduction were carried out with the use of the program APEX2 [34]. 
Absorption corrections, incident beam, and decay corrections were performed with the use of the program SADABS [35]. The structures were solved with the direct-methods program SHELXS and refined with the least-squares program SHELXL [36]. The structural refinements for 1 were straightforward. In cases of $\mathbf{2}$ and $\mathbf{3}$, disordering of $\mathrm{Ca}$ and $\mathrm{Na}$ atoms at the $4 \mathrm{f}(0,1 / 2,1 / 4)$ site is required to reach reasonable thermal parameters. Unrestricted anisotropic models for both 2 and 3 refined successfully and led to $\mathrm{Ca}: \mathrm{Na}$ close to 1:1. The restricted refinements with $\mathrm{Ca}: \mathrm{Na}$ equal to $1: 1$ also yielded similar thermal parameters. Similar disordering behavior of $\mathrm{Ca}$ and $\mathrm{Na}$ at this position has been observed in other isostructural minerals and compounds [6, 8, 23]. Final refinements included anisotropic displacement parameters for all atoms. The program STRUCTURE TIDY was used to standardize the positional parameters [37]. Additional experimental details are given in Table 1 and in the crystallographic information files included in the Supporting Material.

\subsection{X-ray Powder Diffraction Measurements}

X-ray powder diffraction patterns were collected with a Scintag X1 diffractometer with the use of $\mathrm{Cu} \mathrm{K} \alpha$ radiation $(\lambda=1.5418 \AA$ ). The powder sample was loaded into an encapsulated container with curved Kapton windows to minimize the X-ray absorption by the Kapton.

\subsection{Raman Spectroscopy}

Raman spectra of single-crystal samples of $\mathrm{ThSiO}_{4}(\mathbf{1}),\left(\mathrm{Ca}_{0.5} \mathrm{Na}_{0.5}\right)_{2} \mathrm{NaThSi}_{8} \mathrm{O}_{20}(\mathbf{2})$, and $\left(\mathrm{Ca}_{0.5} \mathrm{Na}_{0.5}\right)_{2} \mathrm{NaUSi}_{8} \mathrm{O}_{20}$ (3) were collected on a Renishaw inVia Raman Microscope with excitation lines of $532 \mathrm{~nm}$ and $785 \mathrm{~nm}$. For each compound, at least six different spots were collected on numerous crystals to obtain reproducible data. Due to the radiological hazards

associated with ${ }^{232}$ Th and ${ }^{238} \mathrm{U}$, each sample was placed on a glass drop-slide covered with a transparent coverslip, which was sealed to the slide using an epoxy sealant.

\section{Results and Discussions}




\subsection{Syntheses}

Recent experimental studies and theoretical calculations have shown thorite and huttonite are thermodynamically metastable with respect to two binary oxides at ambient conditions [38, 39]. These results prompt us to employ more chemically active starting materials such as ternary alkali metal/alkali earth metal silicates to explore the actinide silicates. By using $\mathrm{CaSiO}_{3}$ as a starting material and a $\mathrm{Na}_{2} \mathrm{WO}_{4}$ flux (melting point, $971 \mathrm{~K}$ ), we were able to grow single crystal samples of $\mathrm{ThSiO}_{4}$ (1), $\left(\mathrm{Ca}_{0.5} \mathrm{Na}_{0.5}\right)_{2} \mathrm{NaThSi}_{8} \mathrm{O}_{20}$ (2), and $\left(\mathrm{Ca}_{0.5} \mathrm{Na}_{0.5}\right)_{2} \mathrm{NaUSi}_{8} \mathrm{O}_{20}$ (3) at substantially lower temperatures than those previously reported for related compounds [17, 23, 24]. Some of $\mathrm{Na}_{2} \mathrm{WO}_{4}$ clearly participated in the reactions with silicates which resulted in the formation of 2, 3, and a side product $\mathrm{CaWO}_{4}$, as indicated in the PXRD of the $\mathrm{U}$ reaction products (see the Supporting Material). Several rational syntheses using $\mathrm{Na}_{2} \mathrm{SiO}_{4}$ as an additional reactant and other syntheses of 2 at $1003 \mathrm{~K}$ failed at yielding suitable crystals. Considerable etching of silica ampules were observed at the current reaction conditions despite of the carbon coating. Common practice to improve the yields of desired products such as increasing reaction time and reaction temperatures were not further pursued.

\subsection{Structures}

Huttonite (1) crystallizes in a monoclinic monazite-type structure, which has been detailed in the literature [17]. This structure consists of $\mathrm{Th}^{4+}$ cations and discrete tetrahedral $\mathrm{SiO}_{4}{ }^{2-}$ anions as shown in Figure 1. Each Th ion is coordinated by two bidentate and five monodentate silicate ions to form a three-dimensional condensed structure. Our structural results for 1 generally agree with those deduced from the earlier single-crystal studies, but are more precise (see the Supporting Material). For example, the Th-O distances from the current study range from 2.392(4) to 2.793(4) $\AA$, compared to earlier results of 2.40(1) to 2.81(1) $\AA$ [17].

Compounds $\left(\mathrm{Ca}_{0.5} \mathrm{Na}_{0.5}\right)_{2} \mathrm{NaThSi}_{8} \mathrm{O}_{20}(\mathbf{2})$ and $\left(\mathrm{Ca}_{0.5} \mathrm{Na}_{0.5}\right)_{2} \mathrm{NaUSi}_{8} \mathrm{O}_{20}(\mathbf{3})$ are isostructural with several naturally occurring $\mathrm{An}^{4+}(\mathrm{An}=\mathrm{Th}, \mathrm{U})$ containing minerals including steacyite [5], 
turkestanite [6], and arapovite [8]. Both compounds crystallize in tetragonal space group P4/mcc. The structure includes one crystallographically unique An position (site symmetry 422), one Na position (site symmetry 4/m..), one disordered $\mathrm{Na} / \mathrm{Ca}$ position (site symmetry 222.), one $\mathrm{Si}$ position (site symmetry 1), and three $\mathrm{O}$ sites (site symmetry 1, 1, and $m .$. ) (Figure 2). The structure features discrete cage-like oligomeric $\left[\mathrm{Si}_{8} \mathrm{O}_{20}\right]^{8-}$ anions, each of which is built from eight corner-sharing silicate tetrahedra (Figure 2). These octamers are further connected by An ions through terminal $\mathrm{O}(1)$ to form a three-dimensional open framework (Figure 3), which is filled with $\mathrm{Na}^{+}$and $\mathrm{Ca}^{2+}$ cations. Each $\mathrm{An}^{4+}$ cation is surrounded by eight monodentate polyanions in a square antiprismatic geometry. The disordered $\mathrm{Ca}(1) / \mathrm{Na}(1)$ site is eightcoordinate and the $\mathrm{Na}(2)$ site is twelve-coordinate by oxygen atoms.

Selected interatomic distances are listed in Table 2. Because $\mathbf{2}$ and $\mathbf{3}$ are isostructural, only the distances of $\mathbf{3}$ will be discussed. U-O distances in $\mathbf{3}$ are 2.351(4) $\AA$ and they are close to those of 2.32(8) and 2.52(9) $\AA$ found for eight-coordinate $\mathrm{U}^{4+}$ in $\mathrm{USiO}_{4}$ [40]. Si-O distances ranging from $1.575(4)$ to $1.637(4) \AA$, are comparable to those of 1.601(9) to $1.655(8) \AA$ found for $\left[\mathrm{Si}_{8} \mathrm{O}_{20}\right]^{8-}$ units in $\left[\mathrm{NMe}_{4}\right]_{16}\left[\mathrm{Si}_{8} \mathrm{O}_{20}\right][\mathrm{OH}]_{8} \cdot 116 \mathrm{H}_{2} \mathrm{O}$ [41]. $\mathrm{Na}(2)-\mathrm{O}$ distances, 2.710(7) and 3.160(4) $\AA$, are considerably longer than those of 2.399(4) and 2.647(4) $\AA$ for $\mathrm{Ca}(1) / \mathrm{Na}(1)$ owing to a larger coordination number. The structure includes discrete $\mathrm{AnO}_{8}$ square antiprsims separated by bulky $\mathrm{Si}_{8} \mathrm{O}_{20}$ pseudocubes. This results in much longer An-An distances (7.438(2) $\AA$ in 3) than those found in actinide(IV) orthosilicates (3.832(2) $\AA$ in $\mathrm{USiO}_{4}$ [40]).

The cell parameters of the $a$ and $b$ axis and $\mathrm{An}-\mathrm{O}$ and $\mathrm{Na}(2)-\mathrm{O}$ distances found in 2 are larger than those observed in $\mathbf{3}$ (Table 1 and 2), which is consistent with the trend of actinide contraction. For example, the Th-O distances (2.393(3) $\AA$ ) in 2 are approximately $0.04 \AA$ longer than the U-O ones (2.351(4) $\AA$ ) in 3, which is comparable to the difference of $0.05 \AA$ between the ionic radii of eight-coordinate $\mathrm{Th}^{4+}$ and $\mathrm{U}^{4+}$ cations [42]. In contrast, the difference between the cell parameters of the $c$ axis and $\mathrm{Si}-\mathrm{O}$ and $\mathrm{Na}(1)-\mathrm{O}$ distances in $\mathbf{2}$ and $\mathbf{3}$ are within the error bars of values. This anisotropic contraction behavior is owing to a quasi-layered nature of the structure. The three-dimensional structure of $\mathbf{2}$ and $\mathbf{3}$ can be viewed alternatively as layers of face-sharing $\mathrm{Si}_{8} \mathrm{O}_{20}$ and $\mathrm{Na}(2) \mathrm{O}_{12}$ polyhedra in the $a b$ plane intercalated by $\mathrm{An}^{4+}$ and $\mathrm{Ca}(1)^{2+} / \mathrm{Na}(1)^{+}$cations along the $c$ axis (Figure 4). The chemical bonding within $\mathrm{Na}(2) \mathrm{O}_{12}$ 
polyhedra are considered weaker than those within $\mathrm{Ca}(1) / \mathrm{Na}(1) \mathrm{O}_{8}$ polyhedra and the covalent bonding within $\mathrm{Si}_{8} \mathrm{O}_{20}$ moieties. The weaker bonding between $\mathrm{Na}(1)$ and $\mathrm{O}$ atoms is consistent with much larger displacement parameters of $\mathrm{Na}(1)$ than those of other atoms. For example, $U_{\text {eq }}$ for the $\mathrm{Na}(1)$ position in the structure of 2 are $0.079(3) \AA^{2}$ compared to $0.0111(3) \AA^{2}$ for the $\mathrm{Ca}(1) / \mathrm{Na}(1)$ site. Replacing the larger $\mathrm{Th}^{4+}$ cations with smaller $\mathrm{U}^{4+}$ cations is expected to cause a more pronounced response in $\mathrm{Na}(2) \mathrm{O}_{12}$ polyhedra than in others. In fact, the most contraction occurs in $\mathrm{Na}(2)-\mathrm{O}(3)$ distances within the $a b$ plane (2.793(5) $\AA$ in 2 vs. 2.710(7) $\AA$ in 3), while the $\mathrm{Ca}(1) / \mathrm{Na}(1) \mathrm{O}_{8}$ and the $\mathrm{Si}_{8} \mathrm{O}_{20}$ polyhedra remain mostly undistorted (Table 2). Consequently, an anisotropic contraction occurs in the structure of $\mathbf{3}$ compared to that of $\mathbf{2}$.

As stated above, the structures of $\mathbf{2}$ and $\mathbf{3}$ are isotypic with steacyite [5], turkestanite [6], arapovite, $\mathrm{KNaCaThSi}_{8} \mathrm{O}_{20}$ [23], and $\mathrm{RbNaCaThSi}_{8} \mathrm{O}_{20}$ [24]. It is difficult to make detailed comparisons between the structural results of current studies and previous investigations. Mineral studies even those on single crystal samples suffered from various impurities such as metal and water content and imperfection of crystals. Powder studies on $\mathrm{KNaCaThSi}_{8} \mathrm{O}_{20}$ and $\mathrm{RbNaCaThSi}_{8} \mathrm{O}_{20}$ from Knyazev et al. are debatable, mainly due to an unusual lattice expansion of the K-contained compound compared to the $\mathrm{Rb}$-contained phase. In general, our structural results for $\mathbf{2}$ and $\mathbf{3}$ confirm the previous studies such as the $\mathrm{Ca} / \mathrm{Na}$ disordering, but provide more precise data mostly because of better-quality crystals. For example, the Th-O distances are 2.393(3) $\AA$, compared to 2.41(1) $\AA$ in steacyite [43] and 2.44(1) $\AA$ in $\mathrm{RbNaCaThSi}_{8} \mathrm{O}_{20}$ [8].

\subsection{Raman Spectroscopy}

Vibrational spectra of silicate materials have been extensively studied [30, 44]. For tetrahedral $\mathrm{SiO}_{4}{ }^{4-}$ anions in $T_{d}$ symmetry, there are nine normal vibrations characterized by four fundamental vibrational modes including $v_{1}$ (symmetric stretching, Raman active), $v_{2}$ (doubly degenerate bending, Raman active), $v_{3}$ (triply degenerate asymmetric stretching, Raman and infrared active), and $v_{4}$ (triply degenerate bending, Raman and infrared active). Lowering the symmetry of the silicate group can enable the Raman and IR activation of all vibrations and the splitting of degenerate modes. Polymerization of silicate tetrahedra by sharing oxygen atom can 
result in couplings of vibration modes. In general, bands in the $1200-800 \mathrm{~cm}^{-1}, 700-400 \mathrm{~cm}^{-1}$, and $600-400 \mathrm{~cm}^{-1}$ regions have been associated with the stretching modes of tetrahedral silicates, the presence $\mathrm{Si}-\mathrm{O}-\mathrm{Si}$ linkages (polymerized silicates), and the bending modes of silicate units, respectively [30]. External modes involve lattice motions of the silicate tetrahedra, which are typically found at lower frequencies than those of internal modes. Raman spectra of $\mathrm{ThSiO}_{4}(\mathbf{1})$, $\left(\mathrm{Ca}_{0.5} \mathrm{Na}_{0.5}\right)_{2} \mathrm{NaThSi}_{8} \mathrm{O}_{20}(2)$, and $\left(\mathrm{Ca}_{0.5} \mathrm{Na}_{0.5}\right)_{2} \mathrm{NaUSi}_{8} \mathrm{O}_{20}(3)$ with an excitation line of $532 \mathrm{~nm}$ are presented in Figure 5. All three spectra exhibit complex vibrational bands, most of which originate from silicate groups.

The Raman spectrum of huttonite (1) exhibits more vibrational bands than that of thorite owing to a lower symmetry of the structure. Compound $\mathbf{1}$ crystallizes in monoclinic space group $P 2_{1} / n$ with one crystallographically unique $\mathrm{SiO}_{4}$ unit. For the structural class of monazite, the factor-group analysis based on $\mathrm{C}_{2 \mathrm{~h}}$ point group leads to 36 Raman active vibrational modes (18 $A_{g}+18 B_{g}$ ) [45]. Only 22 bands are observed in the $100-1300 \mathrm{~cm}^{-1}$ region for 1 (Figure 5). In a comparison, tetragonal structured thorite has 12 Raman active bands based on the $\mathrm{D}_{4 \mathrm{~h}}$ point group [33]. Detailed assignments of all bands in $\mathbf{1}$ are very difficult without theoretical calculations. In addition, interactions between silicate and metal ions in zircon-type compounds have been observed [31]. A similar scenario is expected in case of the 1. As a result, silicate units may not be treated strictly independently. Nonetheless, the four normal modes of $\mathrm{SiO}_{4}$ tetrahedron can be located near the following bands: $899 \mathrm{~cm}^{-1}$ for asymmetrical stretching $\left(v_{3}\right)$, $875 \mathrm{~cm}^{-1}$ for symmetrical stretching $\left(v_{1}\right), 576 \mathrm{~cm}^{-1}$ for asymmetrical bending $\left(v_{4}\right)$, and $436 \mathrm{~cm}^{-1}$ for symmetrical bending $\left(v_{2}\right)$. These bands are located at the lower frequencies than the corresponding modes in thorite $(914,887,592$, and 438) [33], which indicates a weaker Si-O bonding in 1. This behavior can be attributed to a larger coordination number between Th and silicate groups in $\mathbf{1}$, where each $\mathrm{SiO}_{4}$ tetrahedron bonds to seven Th atoms vs. six in thorite. Most of the vibrational bands in 1 in the region of $400-100 \mathrm{~cm}^{-1}$ can be attributed to external modes of the silicate unit.

Compared to the spectra of $\mathbf{1}$, considerable broadening of almost all Raman bands are observed in those of $\mathbf{2}$ and $\mathbf{3}$. This is because of the strong coupling among $\mathrm{Si}-\mathrm{O}-\mathrm{Si}$ oscillators within the $\mathrm{Si}_{8} \mathrm{O}_{20}$ cage in latter compounds [46]. The Raman spectra of $\mathbf{2}$ and $\mathbf{3}$ are very alike 
except the additional broad band in the range of $500-900 \mathrm{~cm}^{-1}$ in $\mathbf{3}$. This is consistent with the isostructural nature of these two compounds. The $500-900 \mathrm{~cm}^{-1}$ band can be correlated to the optical emission of the $\mathrm{U}^{4+}$ ions, which cannot be detected in the spectra of the same samples with an incident laser radiation at $785 \mathrm{~nm}$ (the Supporting Material). A similar behavior has been observed in the Raman spectra of $\mathrm{Th}_{1-\mathrm{x}} \mathrm{U}_{\mathrm{x}} \mathrm{SiO}_{4}$ samples [33]. IR spectra of cubic $\mathrm{Si}_{8} \mathrm{O}_{20}$ moieties have been calculated by ab initio methods and compared to the experimental data of steacyite [46]. More recently, IR spectra of $\mathrm{KNaCaThSi}_{8} \mathrm{O}_{20}$ have been reported [23]. Based on these results, the vibrational bands in 2 and 3 near $1140 \mathrm{~cm}^{-1}, 1018 \mathrm{~cm}^{-1}, 480-400 \mathrm{~cm}^{-1}$, and 400-100 $\mathrm{cm}^{-1}$ can be attributed to asymmetrical stretching of $\mathrm{Si}-\mathrm{O}-\mathrm{Si}$, asymmetrical stretching of $\mathrm{SiO}_{4}$ tetrahedra, bending modes and external modes of silicates, respectively. The $655 \mathrm{~cm}^{-1}$ band could be one of the characteristic stretching modes for the whole cage. It is close to the calculated value of $630 \mathrm{~cm}^{-1}$ for all out-of-phase symmetrical stretching of Si-O-Si [46].

Raman spectroscopy has attracted lots of interests as a convenient and nondestructive technique for quantitative composition analyses in many mixed oxide systems [47]. This application relies on differentiating the influence of metal $(\mathrm{M})$-oxygen $(\mathrm{O})$ interactions on the vibrational signals of $\mathrm{M}-\mathrm{O}$ or ligand (eg. silicate) sublattices. Recent studies on uranothorite samples $\left(\mathrm{Th}_{1-\mathrm{x}} \mathrm{U}_{\mathrm{x}} \mathrm{SiO}_{4}\right)$ have showed a linear shifting of several Raman modes to higher frequencies as a function of increasing the $U$ incorporation rate [33]. For example, the $v_{1}$ mode of silicate unit follows the equation of $\sigma\left(v_{1}\right)=888+20.9 x$. This indicates a strengthening of the $\mathrm{Si}-\mathrm{O}$ bonding when changing from $\mathrm{Th}$ to $\mathrm{U}$. The discrepancy between $\mathrm{Th}-\mathrm{O}$ and $\mathrm{U}-\mathrm{O}$ interactions may be attributed to the difference in the covalency of $\mathrm{M}-\mathrm{O}$ bonding and the ionic radii of cations $[39,45]$. In contrast, the difference between the vibrational bands of silicate units in 2 and 3 is much smaller. As shown in Figure 5 and tabulated in Table 3, most of corresponding vibrational bands in $\mathbf{2}$ and $\mathbf{3}$ locate at the almost same regions except the $v_{\mathrm{as}}$ of the $\mathrm{Si}-\mathrm{O}-\mathrm{Si}$ mode $\left(1139 \mathrm{~cm}^{-1}\right.$ in 2 vs. $1144 \mathrm{~cm}^{-1}$ in $\left.\mathbf{3}\right)$. This is consistent with the structural results that indicate nearly undistorted $\mathrm{Si}_{8} \mathrm{O}_{20}$ cages changing from Th to U. Covalent $\mathrm{Si}-\mathrm{O}$ interactions are clearly more dominant in structures of $\mathbf{2}$ and $\mathbf{3}$ than in zircon-type structures. In the fore cases, each silicate anions polymerizes with three other units and coordinates to only one metal cation, whereas in the latter structures, each silicate ion is a discrete unit and connected by seven 
metal cations. This may explain a less significant impact of $\mathrm{M}-\mathrm{O}$ interactions on the vibrational modes of silicates in $\mathbf{2}$ and $\mathbf{3}$.

\section{Conclusions}

$\mathrm{ThSiO}_{4}$ (huttonite, 1), $\left.\mathrm{Ca}_{0.5} \mathrm{Na}_{0.5}\right)_{2} \mathrm{NaThSi}_{8} \mathrm{O}_{20}$ (2), and $\left(\mathrm{Ca}_{0.5} \mathrm{Na}_{0.5}\right)_{2} \mathrm{NaUSi}_{8} \mathrm{O}_{20}$ (3) have been prepared at much lower temperatures than previous solid-state studies by using a ternary precursor and a $\mathrm{Na}_{2} \mathrm{WO}_{4}$ flux. These Th and $\mathrm{U}$ compounds are isostructural with some of actinide silicates that occurs naturally and were synthesized under hydrothermal conditions. A similar behavior has been observed in the case of thorite, which can be prepared from a melt or a hydrothermal reaction $[11,48]$. These results suggest the Th and $U$ silicate chemistry in the melts may be invertible with their chemistry in the natural environment. The titled synthetic route from the melts can potentially be used to explore the silicate chemistry of man-made heavier actinides in the geosphere.

Structural results and Raman spectra of 1, 2, and $\mathbf{3}$ provide insight into the An-O interactions and their impact on the vibrational modes of silicate sublattices. Compound $\mathbf{1}$ adopts a condensed monoclinic monazite-type structure with discrete $\mathrm{SiO}_{4}$ tetrahedra. The structure of 2 and 3 features cage-like $\left[\mathrm{Si}_{8} \mathrm{O}_{20}\right]^{8-}$ octamers, which are further connected by $\mathrm{An}^{4+}$ cations to form a three-dimensional open framework. Raman spectra of $\mathbf{1}$ exhibit more complex vibrational bands and lower frequencies for normal modes than those of thorite. This is consistent with a lower structural symmetry and greater Th-O interactions found in $\mathbf{1}$. For $\mathbf{2}$ and $\mathbf{3}$, a less substantial influence of $\mathrm{An}-\mathrm{O}$ interactions on the vibrational bands of $\left[\mathrm{Si}_{8} \mathrm{O}_{20}\right]$ moieties than those in orthosilicates has been observed. These results indicate that Raman spectroscopy alone may not be adequate for quantitative composition analyses of polymerized silicate materials. It could complement with other techniques such as X-ray structural studies, elemental analyses, and other spectroscopy techniques for this purpose. 


\section{Acknowledgments}

This material is based upon work supported by the U.S. Department of Energy, Office of Science, Office of Basic Energy Sciences, Chemical Sciences, Geosciences, and Biosciences Division under contract DE- AC02-06CH11357.

\section{References}

[1] M. Berzelius, Philosophical Magazine Series 26 (1829) 392-393.

[2] A. Pabst, C.O. Hutton, Am. Mineral. 36 (1951) 60-69.

[3] L.R. Stieff, T.W. Stern, A.M. Sherwood, Science 121 (1955) 608-609.

[4] B.W. Anderson, G.F. Claringbull, R.J. Davis, D.K. Hill, Nature (London, U. K.) 190 (1961) 997.

[5] G. Perrault, J.T. Szymanski, Can. Mineral. 20 (1982) 59-63.

[6] L.A. Pautov, A.A. Agakhanov, E.V. Sokolova, Y.K. Kabalov, Zap. Vseross. Mineral. Ova. 126 (1997) 45-55.

[7] Y.P. Li, S.V. Krivovichev, P.C. Burns, Am. Mineral. 85 (2000) 1521-1525.

[8] Y.A. Uvarova, E. Sokolova, F.C. Hawthorne, A.A. Agakhanov, L.A. Pautov, Can. Mineral. 42 (2004) 1005-1011.

[9] J.P. Kaszuba, W.H. Runde, Environ. Sci. Technol. 33 (1999) 4427-4433.

[10] R.J. Silva, H. Nitsche, MRS Bull. 26 (2001) 707-713.

[11] C. Frondel, R.L. Collette, Am. Mineral. 42 (1957) 759-65.

[12] V. Pointeau, A.P. Deditius, F. Miserque, D. Renock, U. Becker, J. Zhang, N. Clavier, N. Dacheux, C. Poinssot, R.C. Ewing, J. Nucl. Mater. 393 (2009) 449-458.

[13] H.-K. Liu, K.-H. Lii, Inorg. Chem. 50 (2011) 5870-5872.

[14] D.T. Costin, A. Mesbah, N. Clavier, N. Dacheux, C. Poinssot, S. Szenknect, J. Ravaux, Inorg. Chem. 50 (2011) 11117-11126.

[15] S. Szenknect, D.T. Costin, N. Clavier, A. Mesbah, C. Poinssot, P. Vitorge, N. Dacheux, Inorg. Chem. 52 (2013) 6957-6968.

[16] C.B. Finch, L.A. Harris, G.W. Clark, Am. Mineral. 49 (1964) 782-5.

[17] M. Taylor, R.C. Ewing, Acta Crystallogr. Sect. B 34 (1978) 1074-1079. 
[18] L.S. Natrajan, A.N. Swinburne, M.B. Andrews, S. Randall, S.L. Heath, Coord. Chem. Rev. 266-267 (2014) 171-193.

[19] A. Rabenau, Angewandte Chemie International Edition in English 24 (1985) 1026-1040.

[20] J. Huang, X. Wang, A.J. Jacobson, J. Mater. Chem. 13 (2003) 191-196.

[21] J.A. Speer, Rev. Mineral. Geochem. 5 (1980) 113-135.

[22] J.D. Woodward, P.M. Almond, T.E. Albrecht-Schmitt, Acta Crystallogr. Sect. E 61 (2005) i58-i60.

[23] A.V. Knyazev, N.G. Chernorukov, M.E. Komshina, Radiochemistry 54 (2012) 431-434.

[24] A.V. Knyazev, M.E. Komshina, A.V. Zhidkov, A.S. Plesovskikh, Russ. J. Inorg. Chem. 58 (2013) 1172-1176.

[25] J.T. Szymanski, D.R. Owens, A.C. Roberts, H.G. Ansell, G.Y. Chao, Can. Mineral. 20 (1982) 65-75.

[26] C.-S. Lee, S.-L. Wang, K.-H. Lii, Journal of the American Chemical Society 131 (2009) 15116-15117.

[27] C.-S. Lee, C.-H. Lin, S.-L. Wang, K.-H. Lii, Angewandte Chemie International Edition 49 (2010) 4254-4256.

[28] C.-L. Chen, Q.B. Nguyen, C.-S. Chen, K.-H. Lii, Inorg. Chem. 51 (2012) 7463-7465.

[29] M.D. Karkhanavala, Current Sci. 25 (1956) 166-167.

[30] P. McMillan, Am. Mineral. 69 (1984) 622-644.

[31] R.W.G. Syme, D.J. Lockwood, H.J. Kerr, J. Phys. C. 10 (1977) 1335.

[32] M.P. Lahalle, J.C. Krupa, M. Lepostollec, J.P. Forgerit, J. Solid State Chem. 64 (1986) 181-187.

[33] N. Clavier, S. Szenknect, D.T. Costin, A. Mesbah, C. Poinssot, N. Dacheux, Spectrochim. Acta, Part A 118 (2014) 302-307.

[34] Bruker. APEX2 Version 2009.5-1 and SAINT Version 7.34a Data Collection and Processing Software; Bruker Analytical X-Ray Instruments, Inc.: Madison, WI, USA, 2009.

[35] Bruker. SMART Version 5.054 Data Collection and SAINT-Plus Version 6.45a Data Processing Software for the SMART System; Bruker Analytical X-Ray Instruments, Inc., Madison, WI, USA, 2003.

[36] G.M. Sheldrick, Acta Crystallogr. Sect. A 64 (2008) 112-122.

[37] L.M. Gelato, E. Parthe, J. Appl. Crystallogr. 20 (1987) 139-143.

[38] L. Mazeina, S.V. Ushakov, A. Navrotsky, L.A. Boatner, Geochimica et Cosmochimica Acta 69 (2005) 4675-4683.

[39] I. Shein, K. Shein, A. Ivanovskii, Phys Chem Minerals 33 (2006) 545-552.

[40] L.H. Fuchs, E. Gebert, Am. Mineral. 43 (1958) 243-248.

[41] M. Wiebcke, D. Hoebbel, J. Chem. Soc., Dalton Trans. (1992) 2451-2455.

[42] R. Shannon, Acta Crystallogr. Sect. A 32 (1976) 751-767.

[43] P. Richard, G. Perrault, Acta Crystallogr. Sect. B 28 (1972) 1994-1999.

[44] K. Nakamoto, Infrared and Raman Spectra of Inorganic and Coordination Compounds. 4th ed.; Wiley, New York, 1986. 
[45] J. Heuser, A.A. Bukaemskiy, S. Neumeier, A. Neumann, D. Bosbach, Prog. Nucl. Energy 72 (2014) 149-155.

[46] M. Handke, W. Jastrzębski, J. Mol. Struct. 744-747 (2005) 671-675.

[47] R. Rao, R.K. Bhagat, N.P. Salke, A. Kumar, Appl. Spectrosc. 68 (2014) 44-48.

[48] L.H. Fuchs, Am. Mineral. 43 (1958) 367-368. 


\section{Table 1.}

Crystal data and structure refinements for $\left(\mathrm{Ca}_{0.5} \mathrm{Na}_{0.5}\right)_{2} \mathrm{NaAnSi}_{8} \mathrm{O}_{20}(\mathrm{An}=\mathrm{Th}, \mathrm{U}){ }^{\mathrm{a}}$

\begin{tabular}{lll}
\hline & $\left(\mathrm{Ca}_{0.5} \mathrm{Na}_{0.5}\right)_{2} \mathrm{NaThSi}_{8} \mathrm{O}_{20}$ & $\left(\mathrm{Ca}_{0.5} \mathrm{Na}_{0.5}\right)_{2} \mathrm{NaUSi}_{8} \mathrm{O}_{20}$ \\
\hline $\mathrm{FW}$ & 862.82 & 868.81 \\
$a(\AA)$ & $7.497(2)$ & $7.438(2)$ \\
$c(\AA)$ & $14.886(4)$ & $14.888(3)$ \\
$V\left(\AA^{3}\right)$ & $836.6(4)$ & $823.7(3)$ \\
$\rho_{\mathrm{c}}\left(\mathrm{g} / \mathrm{cm}^{3}\right)$ & 3.425 & 3.503 \\
$\mu\left(\mathrm{cm}^{-1}\right)$ & 99.58 & 109.15 \\
$R(F)^{\mathrm{b}}$ & 0.0231 & 0.0292 \\
$R_{w}\left(F_{o}^{2}\right)^{\mathrm{c}}$ & 0.0563 & 0.0793 \\
\hline
\end{tabular}

${ }^{\mathrm{a}}$ For both structures, $Z=2$, Space group $=P 4 / m c c, \lambda=0.71073 \AA$, and $T=100(2) \mathrm{K}$. ${ }^{\mathrm{b}} R(F)=$ $\Sigma|| F_{\mathrm{o}}|-| F_{c}|| / \Sigma\left|F_{\mathrm{o}}\right|$ for $F_{o}{ }^{2}>2 \sigma\left(F_{\mathrm{o}}{ }^{2}\right) .{ }^{\mathrm{c}} R_{w}\left(F_{\mathrm{o}}{ }^{2}\right)=\left\{\Sigma\left[w\left(F_{\mathrm{o}}{ }^{2}-F_{c}{ }^{2}\right)^{2}\right] / \Sigma w F_{\mathrm{o}}{ }^{4}\right\}^{1 / 2}$ for all data. $w^{-1}=\sigma^{2}\left(F_{\mathrm{o}}{ }^{2}\right)+\left(q F_{\mathrm{o}}{ }^{2}\right)^{2}$ for $F_{\mathrm{o}}{ }^{2} \geq 0 ; w^{-1}=\sigma^{2}\left(F_{o}{ }^{2}\right)$ for $F_{\mathrm{o}}{ }^{2}<0 . q=0.0289$ for $\left(\mathrm{Ca}_{0.5} \mathrm{Na}_{0.5}\right)_{2} \mathrm{NaThSi}_{8} \mathrm{O}_{20}, 0.0450$ for $\left(\mathrm{Ca}_{0.5} \mathrm{Na}_{0.5}\right)_{2} \mathrm{NaUSi}_{8} \mathrm{O}_{20}$. 
Table 2.

Selected interatomic distances $(\AA)$ and angles $(\mathrm{deg})$ for $\left(\mathrm{Ca}_{0.5} \mathrm{Na}_{0.5}\right)_{2} \mathrm{NaAnSi}_{8} \mathrm{O}_{20}$.

\begin{tabular}{|c|c|c|}
\hline Distance & $\left(\mathrm{Ca}_{0.5} \mathrm{Na}_{0.5}\right)_{2} \mathrm{NaThSi}_{8} \mathrm{O}_{20}$ & $\left(\mathrm{Ca}_{0.5} \mathrm{Na}_{0.5}\right)_{2} \mathrm{NaUSi}_{8} \mathrm{O}_{20}$ \\
\hline $\mathrm{Ca} / \mathrm{Na}(1)-\mathrm{O}(1) \times 4$ & $2.410(3)$ & $2.399(4)$ \\
\hline $\mathrm{Ca} / \mathrm{Na}(1)-\mathrm{O}(2) \times 4$ & $2.652(3)$ & $2.647(4)$ \\
\hline $\mathrm{Na}(2)-\mathrm{O}(1) \times 8$ & $3.169(3)$ & $3.160(4)$ \\
\hline $\mathrm{Na}(2)-\mathrm{O}(3) \times 4$ & $2.793(5)$ & $2.710(7)$ \\
\hline $\mathrm{An}(1)-\mathrm{O}(1) \times 8$ & $2.393(3)$ & $2.351(4)$ \\
\hline $\mathrm{Si}(1)-\mathrm{O}(1)$ & $1.570(3)$ & $1.575(4)$ \\
\hline $\mathrm{Si}(1)-\mathrm{O}(2)$ & $1.622(3)$ & $1.614(4)$ \\
\hline $\mathrm{Si}(1)-\mathrm{O}(2)$ & $1.634(3)$ & $1.637(4)$ \\
\hline $\mathrm{Si}(1)-\mathrm{O}(3)$ & $1.616(2)$ & $1.619(2)$ \\
\hline $\mathrm{O}(1)-\mathrm{Si}(1)-\mathrm{O}(2)$ & $113.7(2)$ & $114.3(2)$ \\
\hline $\mathrm{O}(1)-\mathrm{Si}(1)-\mathrm{O}(2)$ & $105.7(2)$ & $105.2(2)$ \\
\hline $\mathrm{O}(1)-\mathrm{Si}(1)-\mathrm{O} 3)$ & $110.6(2)$ & $110.4(3)$ \\
\hline $\mathrm{O}(2)-\mathrm{Si}(1)-\mathrm{O}(2)$ & $108.5(2)$ & $108.3(3)$ \\
\hline $\mathrm{O}(2)-\mathrm{Si}(1)-\mathrm{O}(3)$ & $107.9(2)$ & $108.0(3)$ \\
\hline $\mathrm{O}(2)-\mathrm{Si}(1)-\mathrm{O}(3)$ & $110.5(2)$ & $110.6(3)$ \\
\hline
\end{tabular}


Table 3.

Major Raman vibrational frequencies $\left(\mathrm{cm}^{-1}\right)$ of $\mathrm{ThSiO}_{4}(\mathbf{1}),\left(\mathrm{Ca}_{0.5} \mathrm{Na}_{0.5}\right)_{2} \mathrm{NaThSi}_{8} \mathrm{O}_{20}(\mathbf{2})$, and $\left(\mathrm{Ca}_{0.5} \mathrm{Na}_{0.5}\right)_{2} \mathrm{NaUSi}_{8} \mathrm{O}_{20}(3)$ with an excitation line of $532 \mathrm{~nm}$ in the $100-1300 \mathrm{~cm}^{-1}$ region.

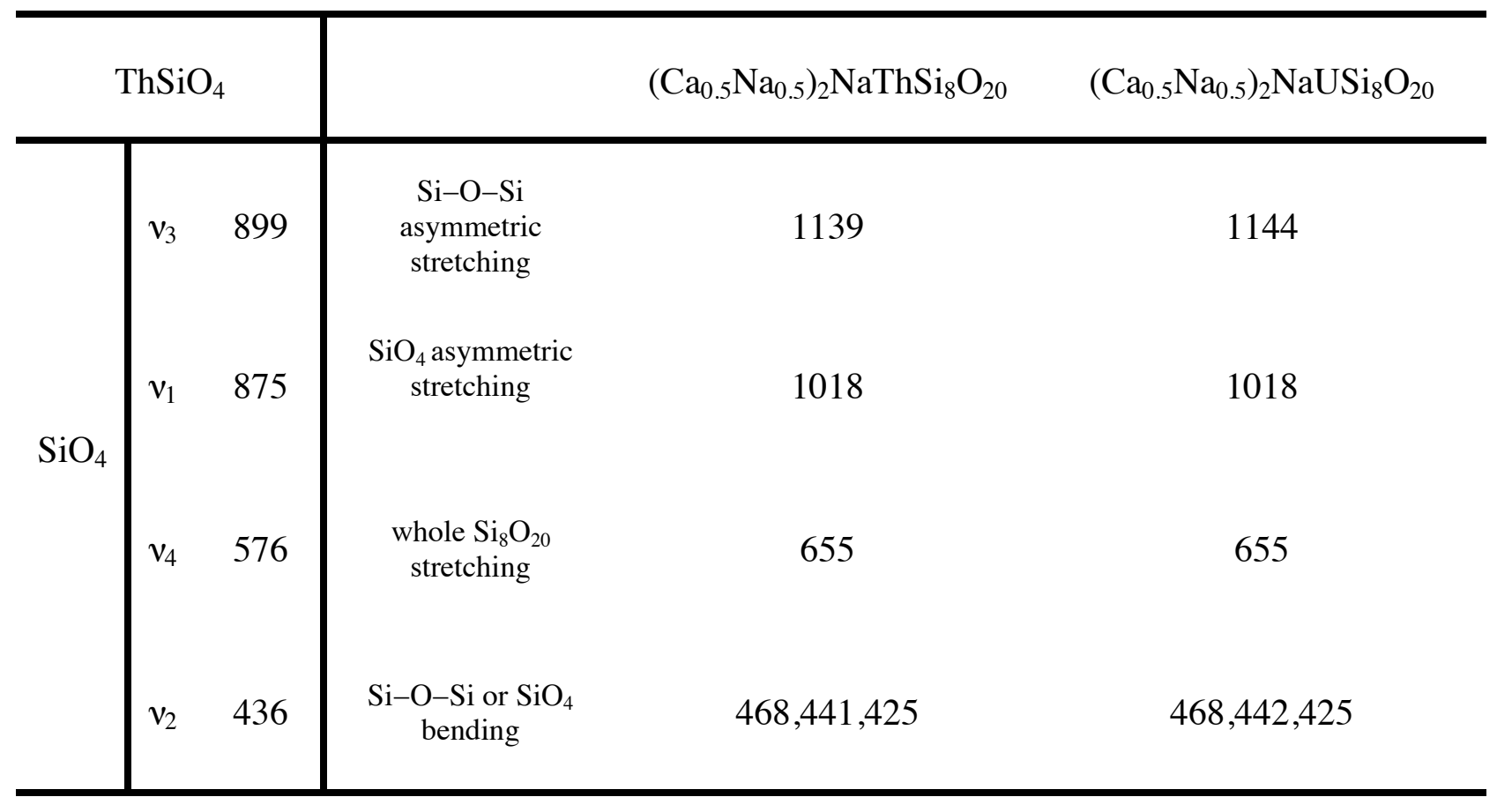




\section{Figure 1.}

a) An illustration of the coordination environment for the $\mathrm{Th}$ atom in $\mathrm{ThSiO}_{4}(\mathbf{1})$;

b) A polyhedral presentation of the three-dimensional structure of $\mathbf{1}$ down the $b$ axis.

a)

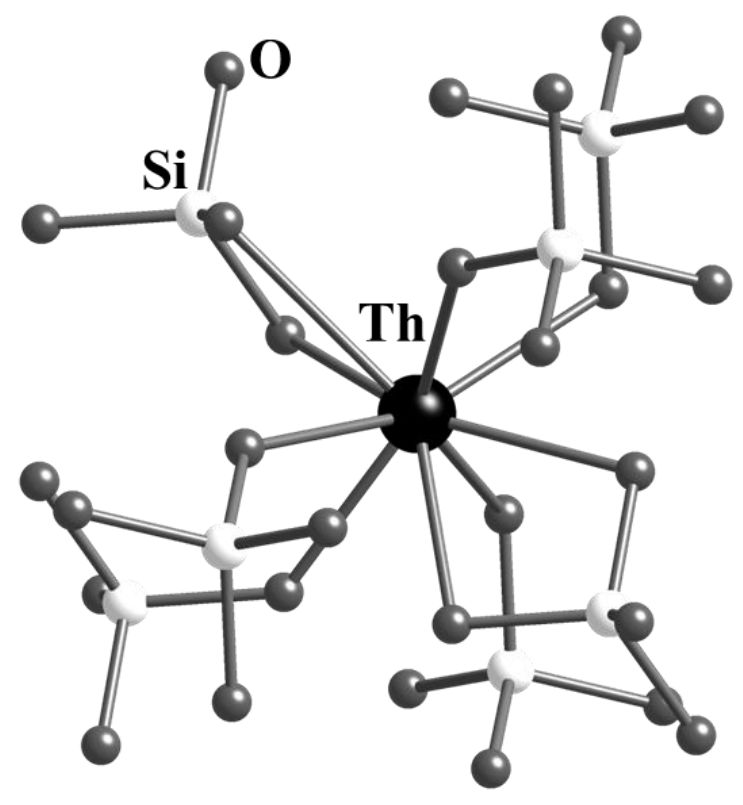

b)

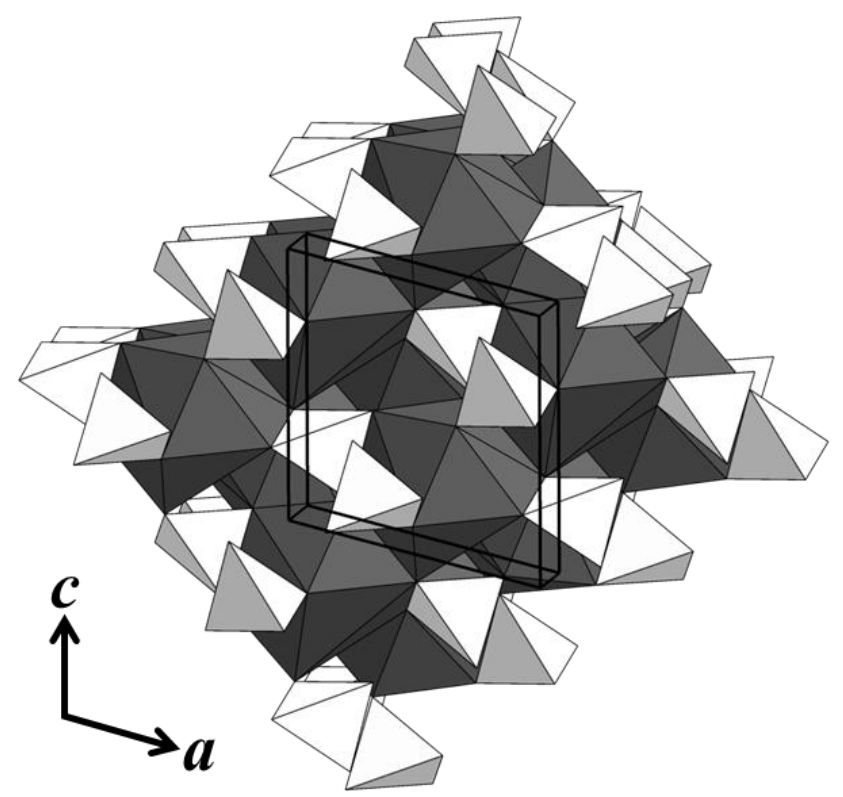


Figure 2.

Local coordination environments for the $\mathrm{An}, \mathrm{Ca} / \mathrm{Na}$, and $\mathrm{Na}$ sites in the structure of $\left(\mathrm{Ca}_{0.5} \mathrm{Na}_{0.5}\right)_{2} \mathrm{NaAnSi}_{8} \mathrm{O}_{20}(\mathrm{An}=\mathrm{Th}, \mathrm{U})$.

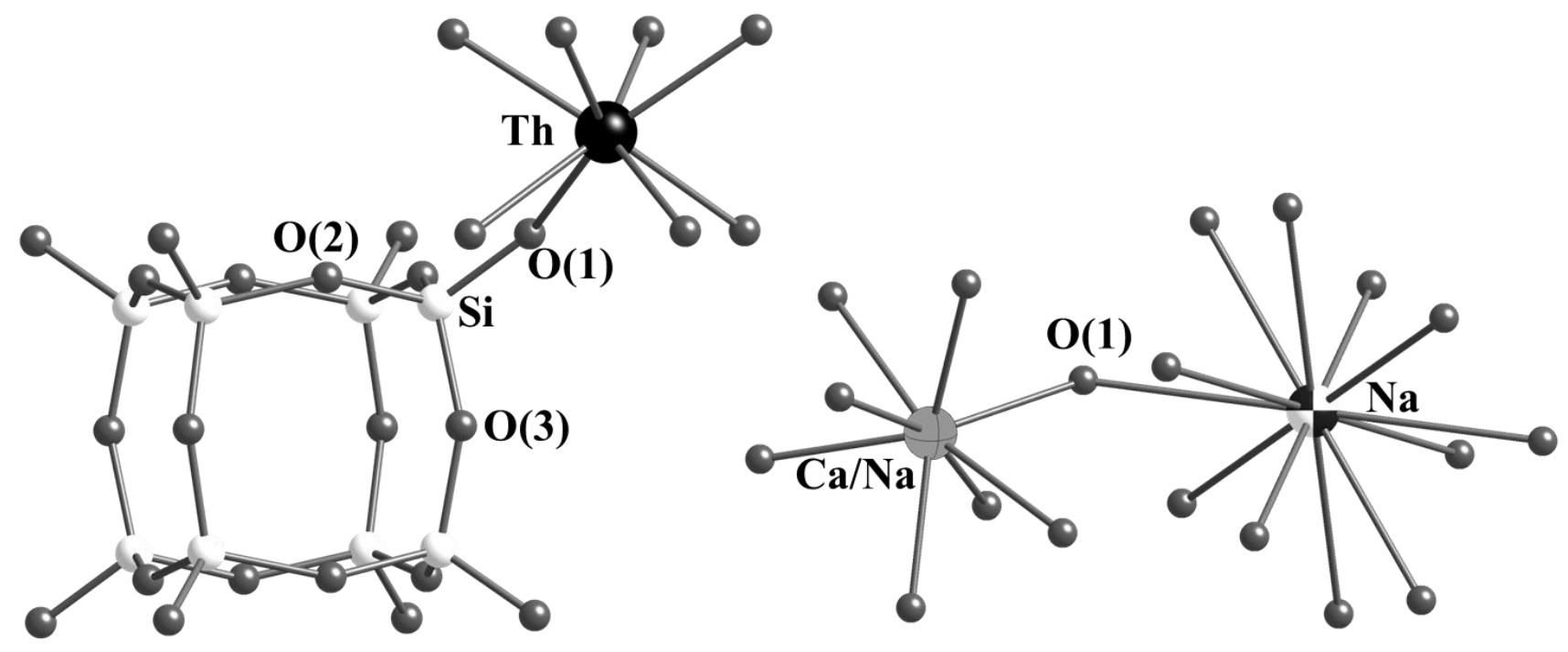




\section{Figure 3.}

A unit cell of three-dimensional framework of $\left(\mathrm{Ca}_{0.5} \mathrm{Na}_{0.5}\right)_{2} \mathrm{NaAnSi}_{8} \mathrm{O}_{20}$ along the $a$ axis. $\mathrm{AnO}_{8}$ square antiprisms and $\mathrm{SiO}_{4}$ tetrahedra are shown in black and grey polyhedra, respectively. $\mathrm{Ca} / \mathrm{Na}-\mathrm{O}$ and $\mathrm{Na}-\mathrm{O}$ interactions are omitted for the purpose of clarity.

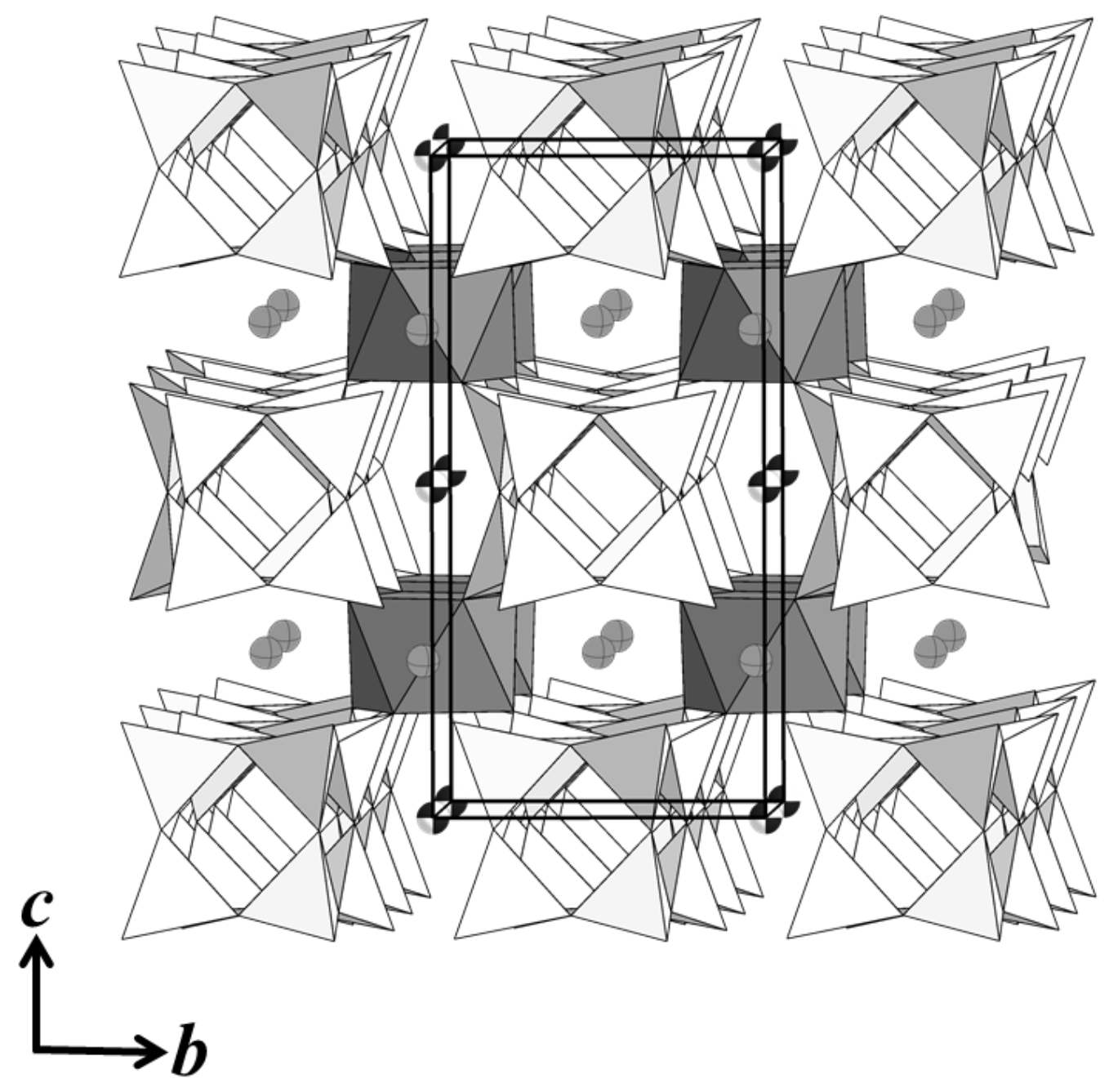




\section{Figure 4.}

A quasi-layered structure of $\left(\mathrm{Ca}_{0.5} \mathrm{Na}_{0.5}\right)_{2} \mathrm{NaAnSi}_{8} \mathrm{O}_{20}$ along the $a b$ plane. When changing from $\mathrm{An}=\mathrm{Th}$ to $\mathrm{An}=\mathrm{U}, \mathrm{Na}-\mathrm{O}(3)$ bonding on the $a b$ plane contract the most compared to others. $\mathrm{An}-\mathrm{O}$ and $\mathrm{Ca} / \mathrm{Na}-\mathrm{O}$ interactions are omitted for the purpose of clarity.

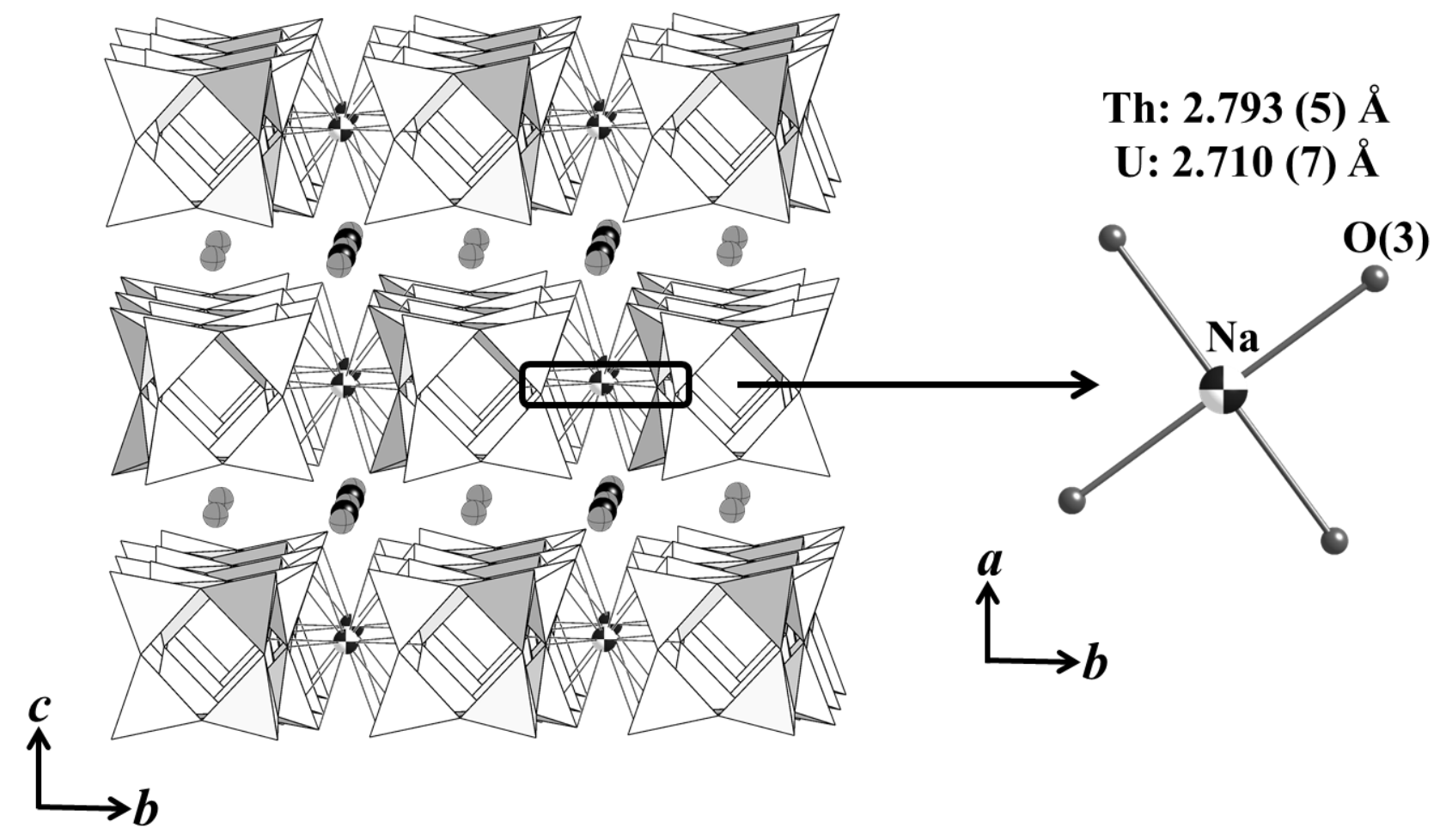


Figure 5.

Raman spectra of $\mathrm{ThSiO}_{4}(\mathbf{1}),\left(\mathrm{Ca}_{0.5} \mathrm{Na}_{0.5}\right)_{2} \mathrm{NaThSi}_{8} \mathrm{O}_{20}(\mathbf{2})$, and $\left(\mathrm{Ca}_{0.5} \mathrm{Na}_{0.5}\right)_{2} \mathrm{NaUSi}_{8} \mathrm{O}_{20}(\mathbf{3})$ with an excitation line of $532 \mathrm{~nm}$ in the $100-1300 \mathrm{~cm}^{-1}$ region.

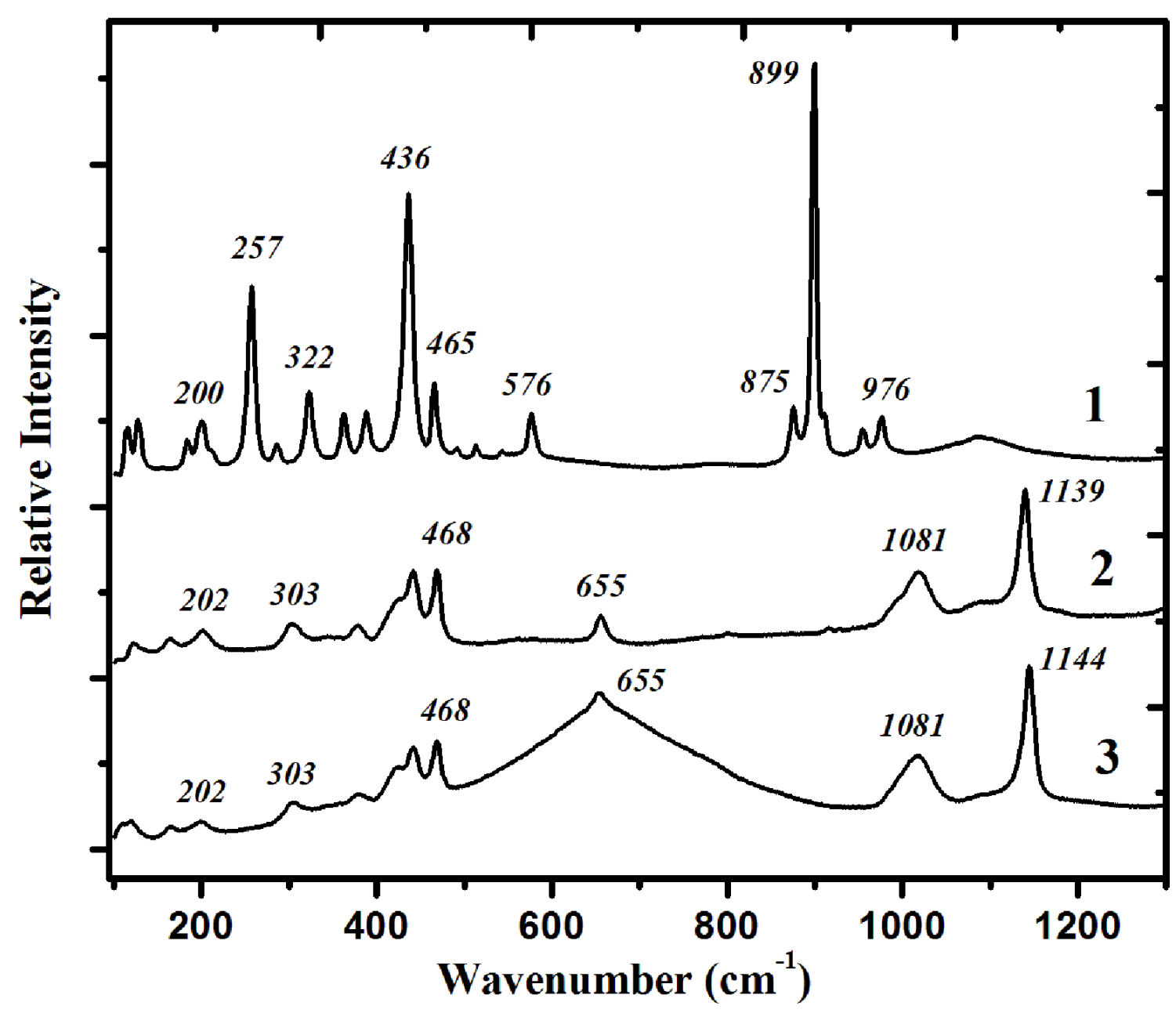



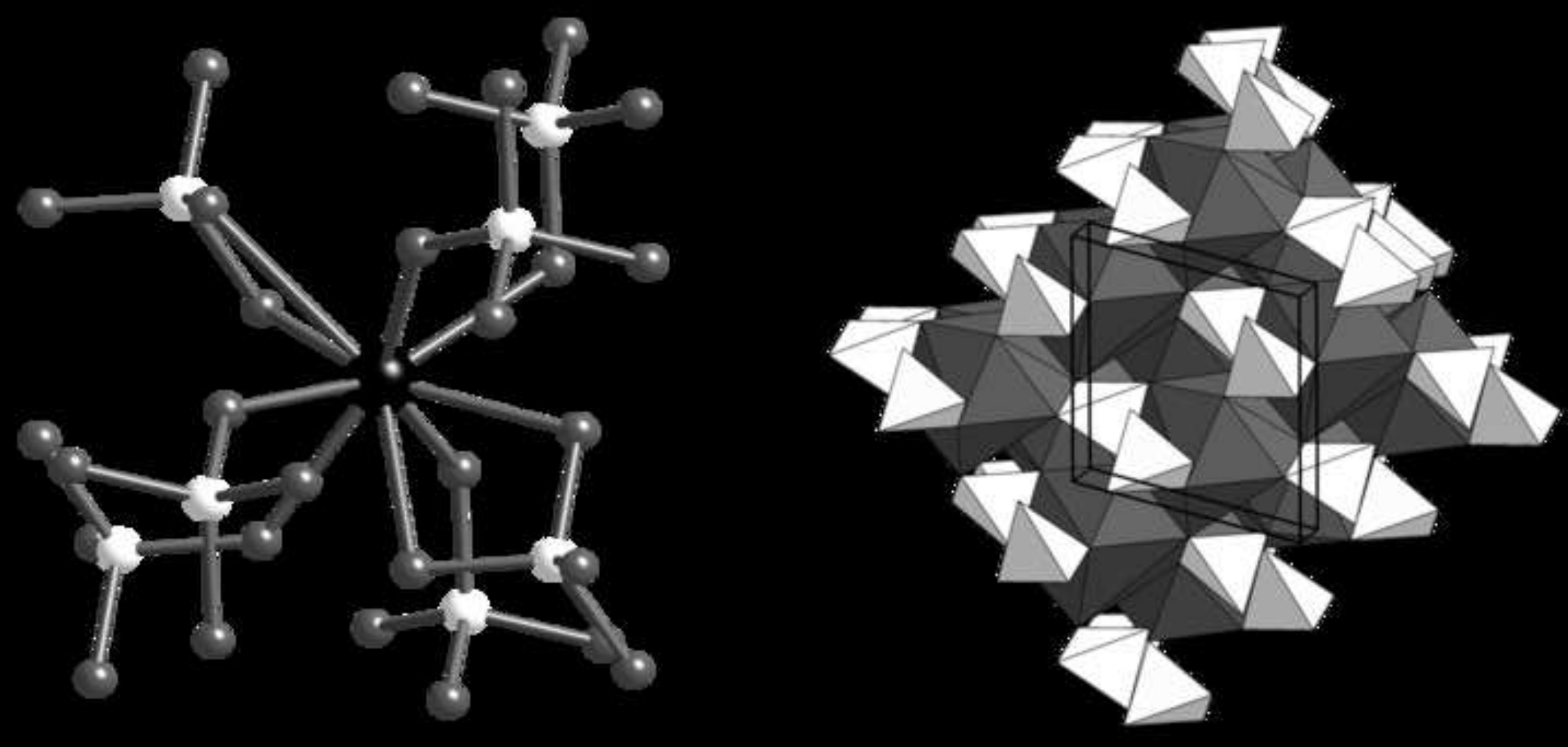
figure 2

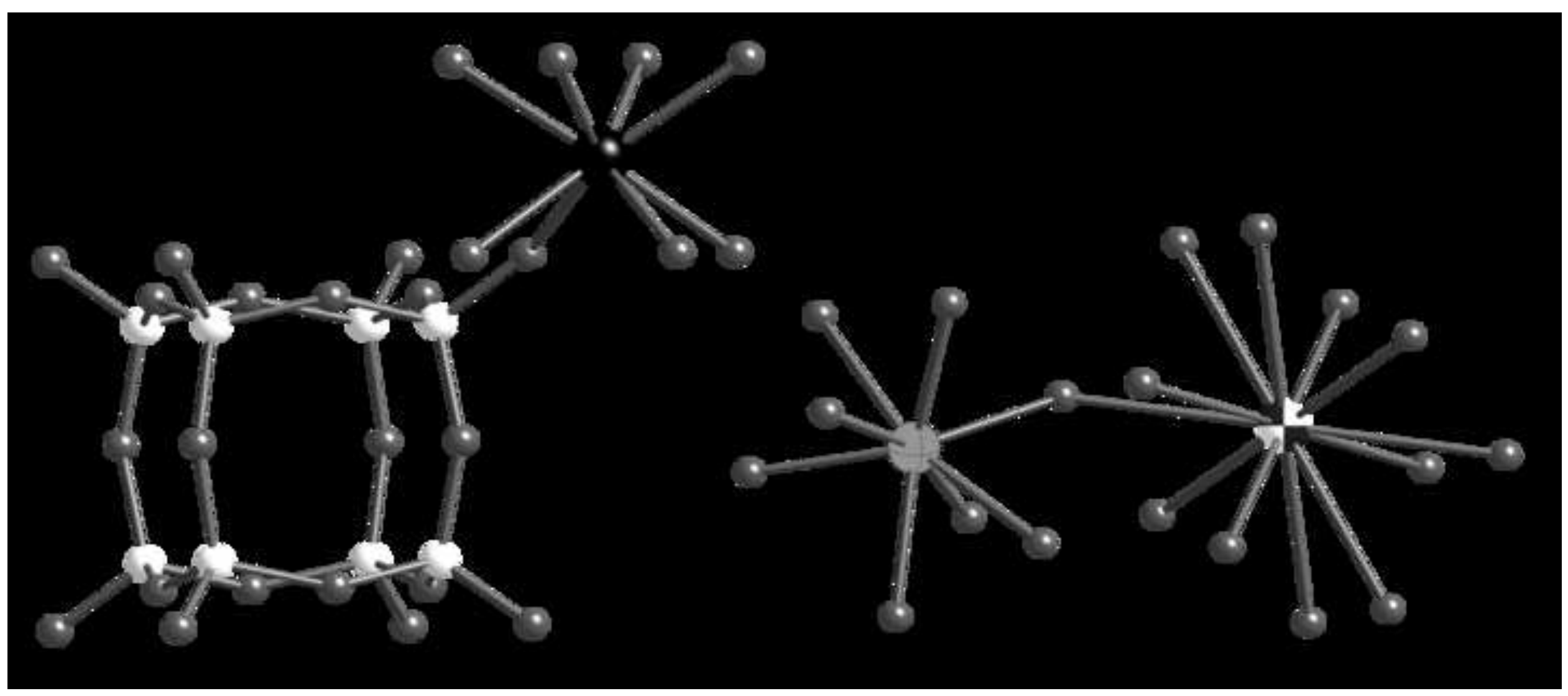




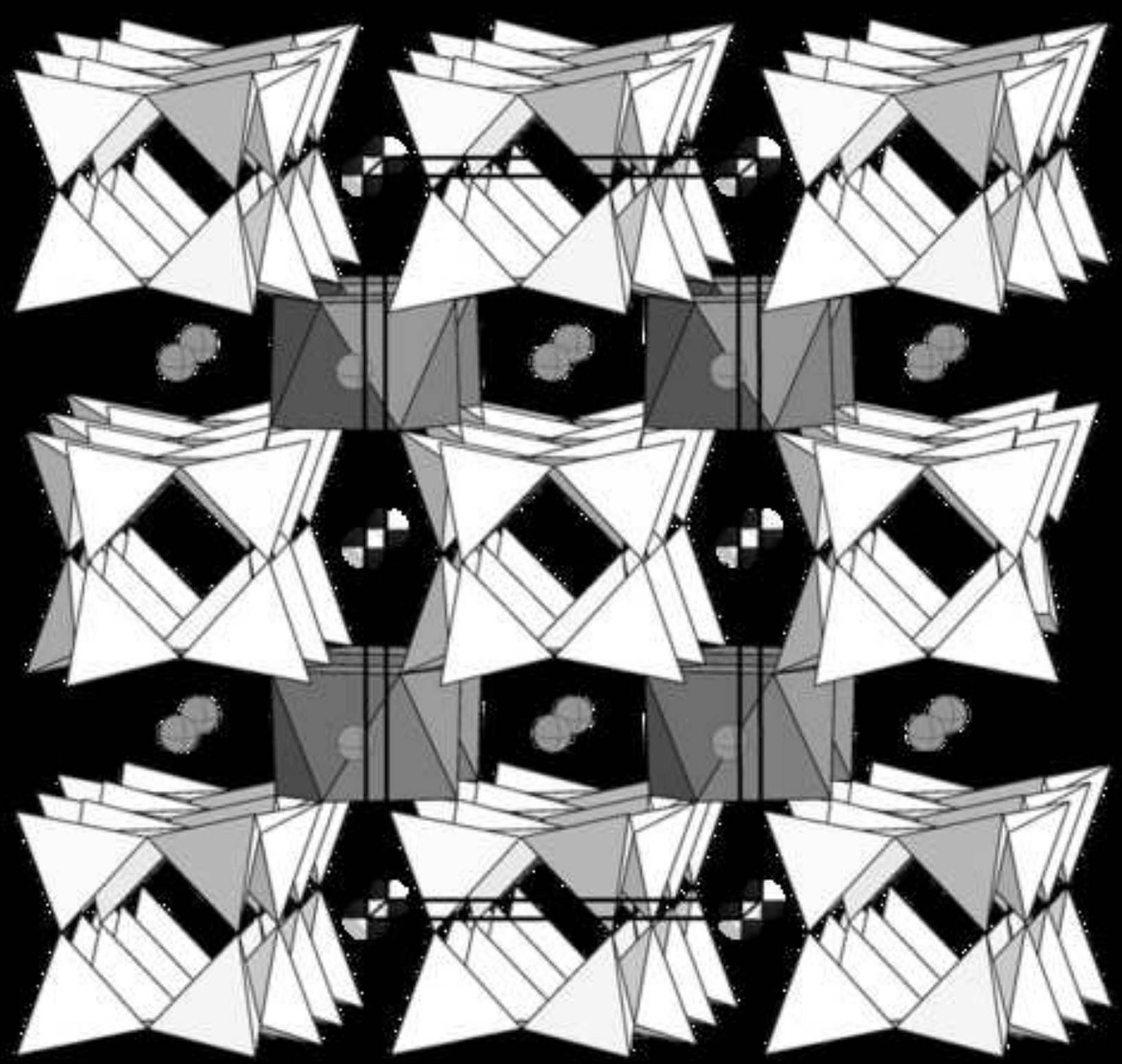



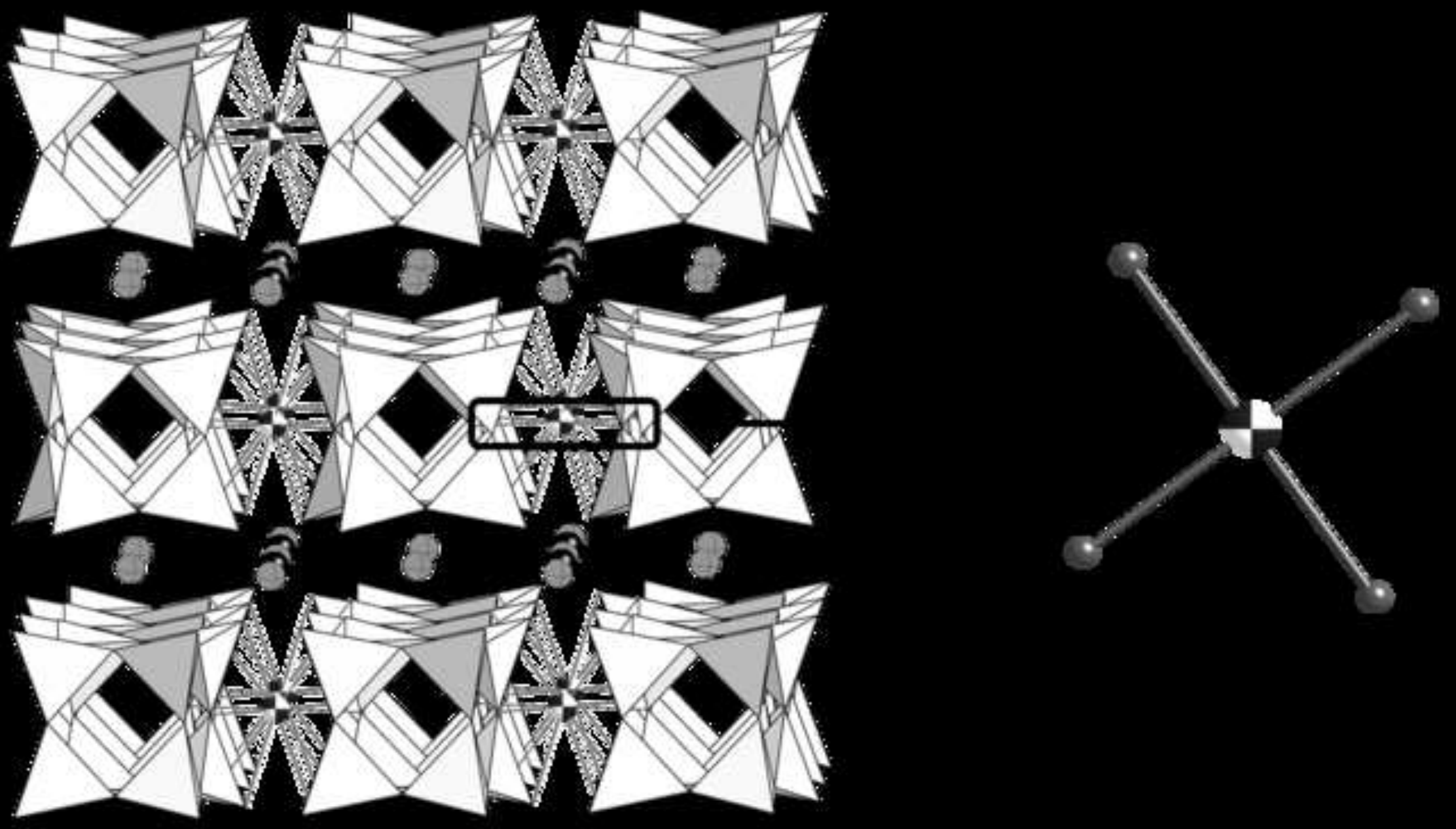
figure 5

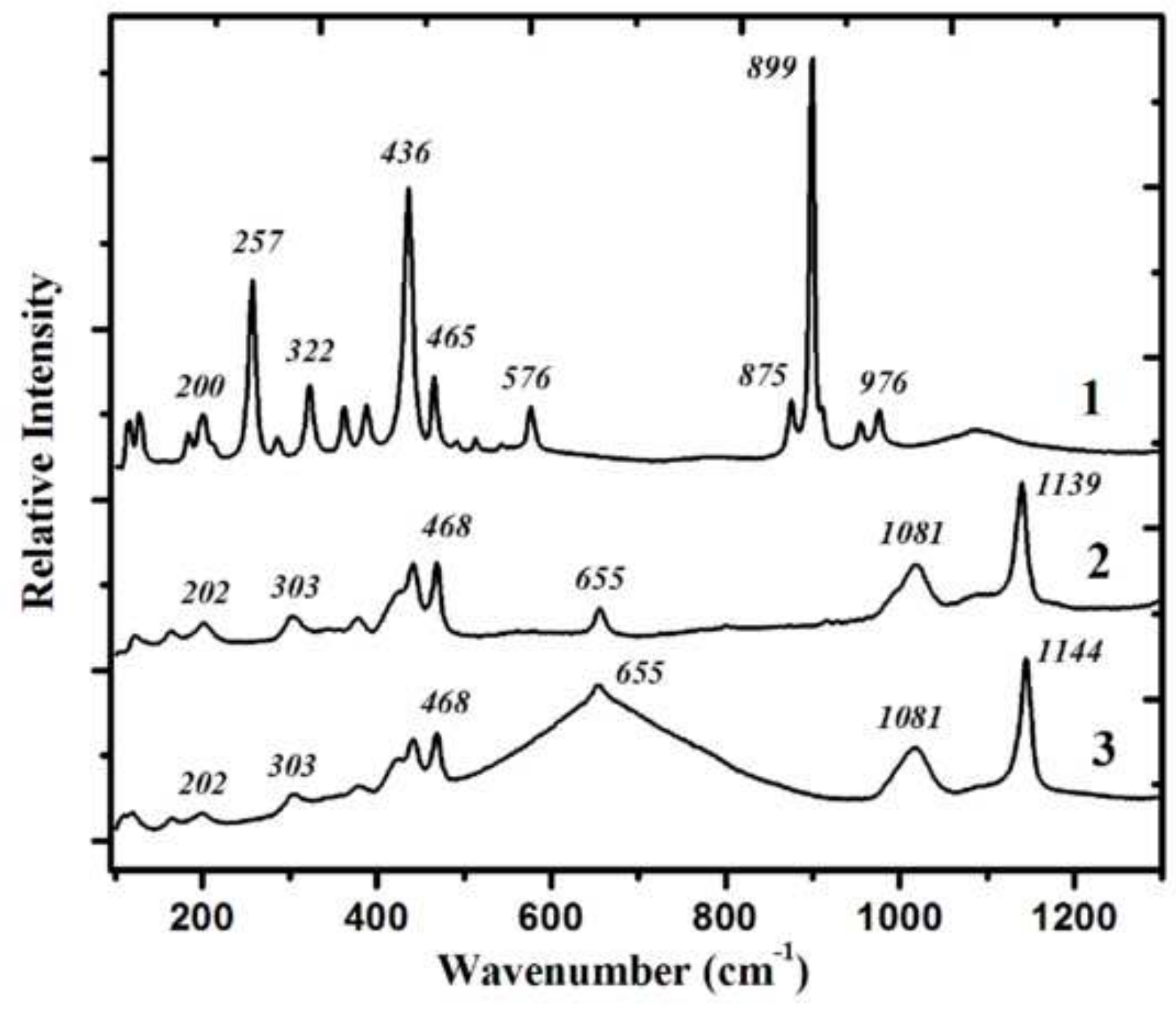




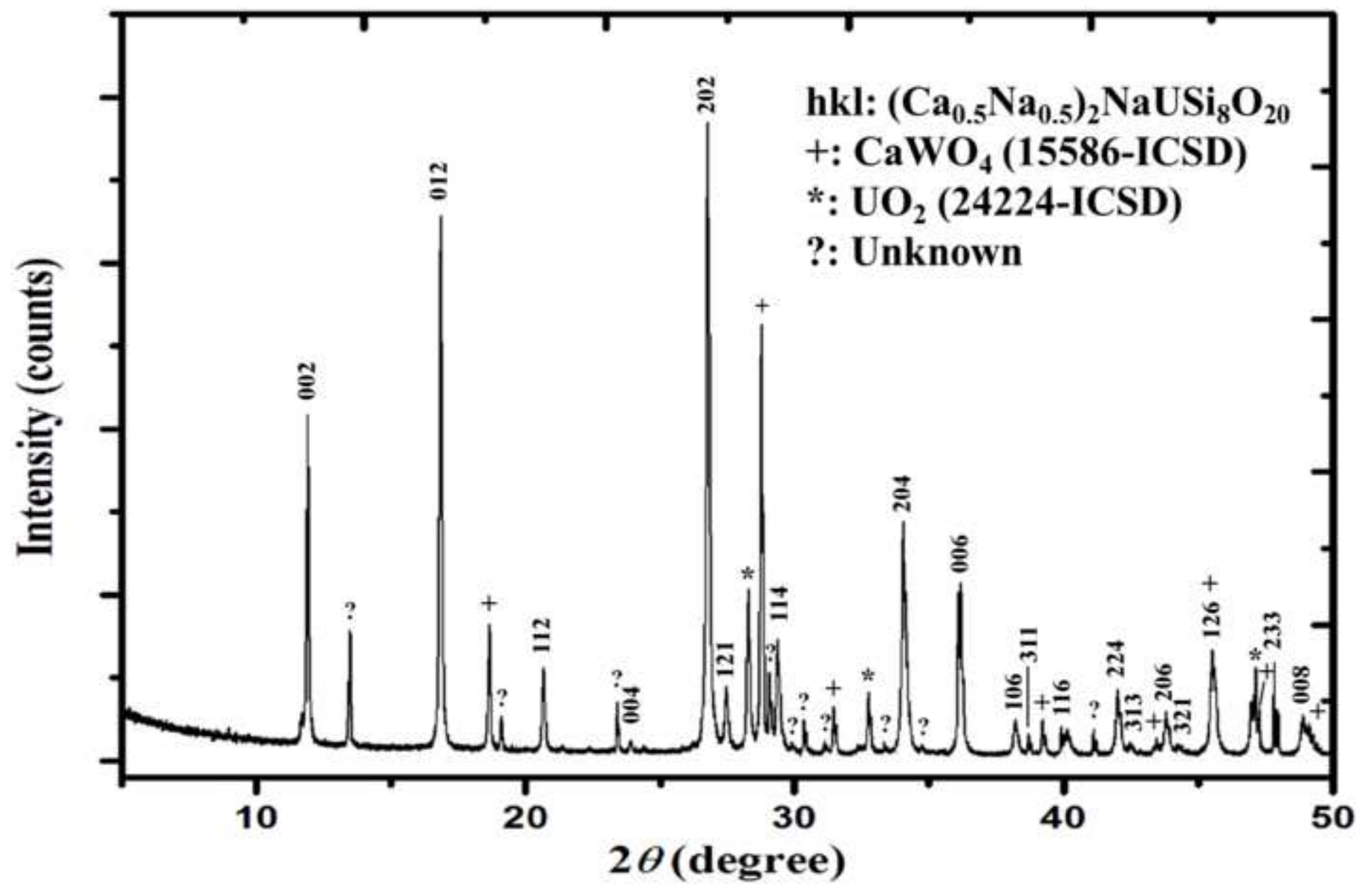




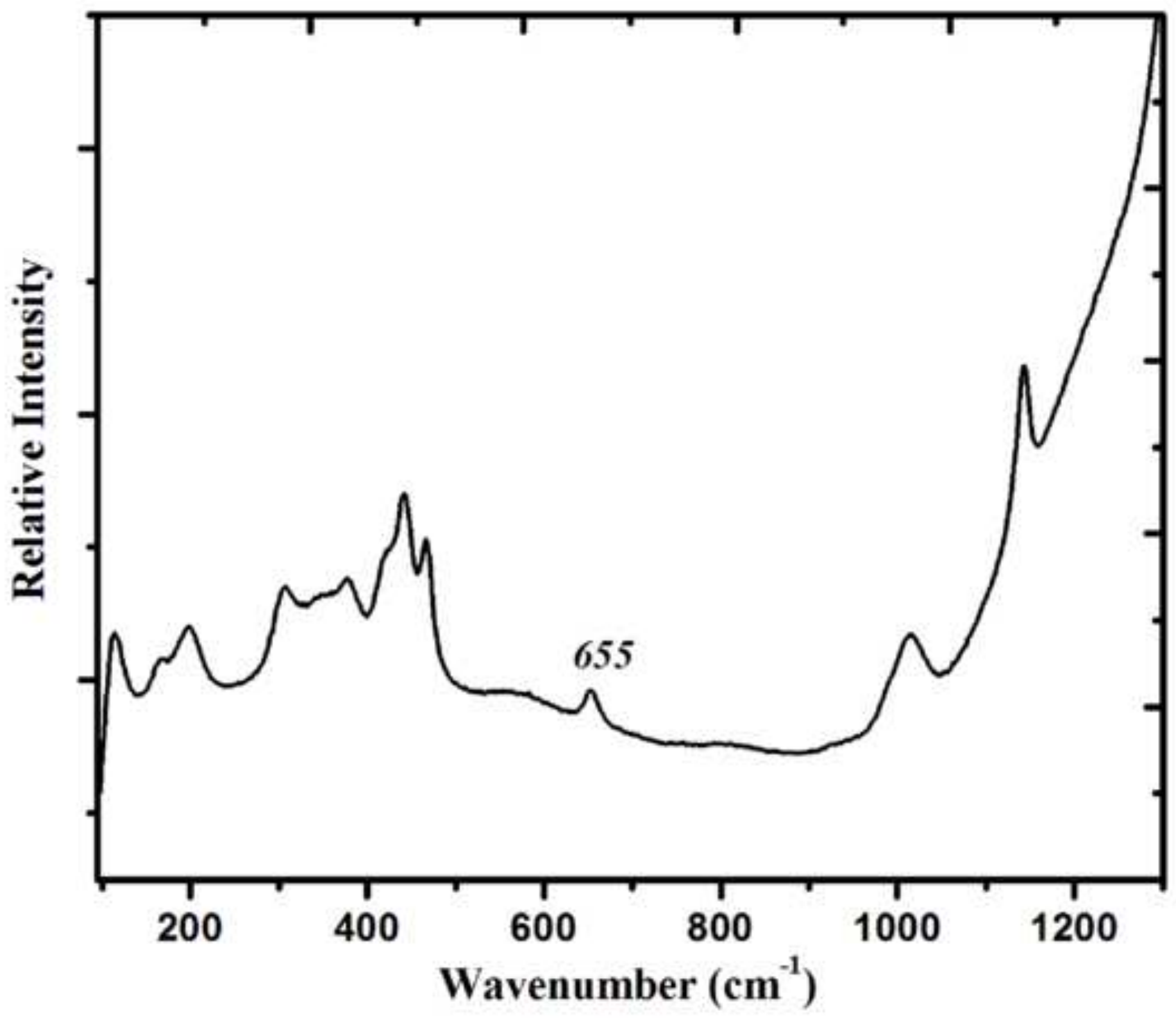




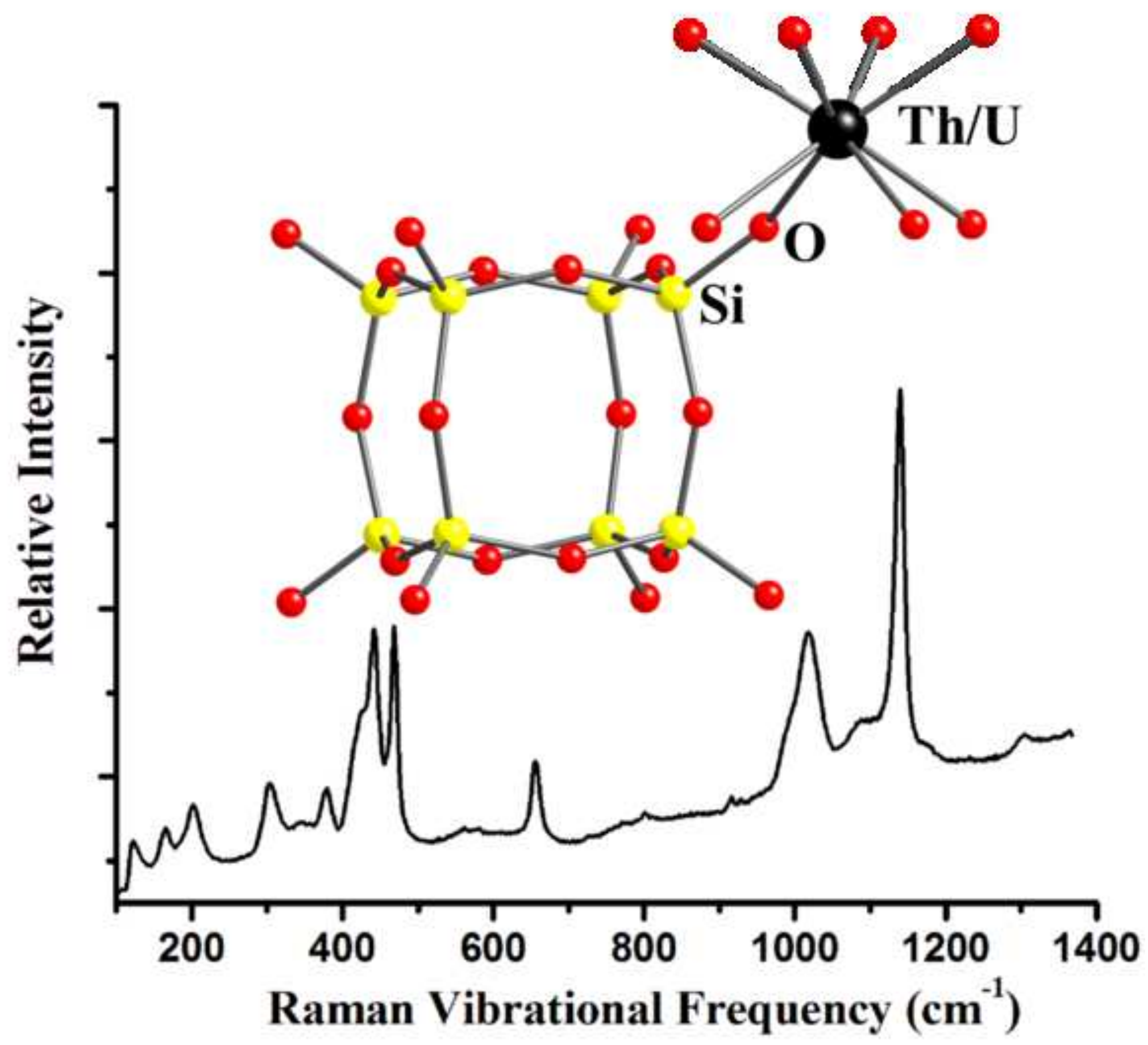


Highlights (for review)

Single crystal growth of three tetravalent actinide silicates from melts.
Single-crystal structures and Raman spectra of $\left(\mathrm{Ca}_{0.5} \mathrm{Na}_{0.5}\right)_{2} \mathrm{NaAnSi}_{8} \mathrm{O}_{20}(\mathrm{An}=\mathrm{Th}, \mathrm{U})$.
First report of Raman spectrum of huttonite on single crystal samples.

Single crystal growth of three tetravalent actinide silicates from melts.
Single-crystal structures and Raman spectra of $\left(\mathrm{Ca}_{0.5} \mathrm{Na}_{0.5}\right)_{2} \mathrm{NaAnSi}_{8} \mathrm{O}_{20}(\mathrm{An}=\mathrm{Th}, \mathrm{U})$.
First report of Raman spectrum of huttonite on single crystal samples.

Single crystal growth of three tetravalent actinide silicates from melts.
Single-crystal structures and Raman spectra of $\left(\mathrm{Ca}_{0.5} \mathrm{Na}_{0.5}\right)_{2} \mathrm{NaAnSi} \mathrm{Na}_{8} \mathrm{O}$
First report of Raman spectrum of huttonite on single crystal samples. First report of Raman spectrum of huttonite on single crystal samples.

Single crystal growth of three tetravalent actinide silicates from melts.
Single-crystal structures and Raman spectra of $\left(\mathrm{Ca}_{0.5} \mathrm{Na}_{0.5}\right)_{2} \mathrm{NaAnSi}_{8} \mathrm{O}_{20}(\mathrm{An}=\mathrm{Th}, \mathrm{U})$. (1) (1)

Single crystal growth of three tetravalent actinide silicates from melts.
Single-crystal structures and Raman spectra of $\left(\mathrm{Ca}_{0.5} \mathrm{Na}_{0.5}\right)_{2} \mathrm{NaAnSi}_{8} \mathrm{O}_{20}(\mathrm{An}=\mathrm{Th}, \mathrm{U})$.
First report of Raman spectrum of huttonite on single crystal samples.

(1)

(1)

(1)

(1)

(1)

$\sqrt{2}$

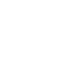

